Winchester, and on returning to live in Guernsey he was elected consulting surgeon to the Southampton Eye Hospital. During the war he served as an ophthalmic specialist with the rank of Captain, R.A.M.C.

\title{
PROFESSOR JOHANNES VON KRIES
}

WE regret to note the recent death of PROF. vON KRIES, professor of physiology, in Freiburg i.B. In addition to being one of the editors of the 3rd edition of Helmholtz's physiological optics, he is well-known for his work on colour vision, and was a strong upholder of the duplicity and trichromatic theories.

\section{NOTES}

Royal London THE Annual Dinner of Past and Present Ophthalmic Hospital Students of the Royal London Ophthalmic Annual Dinner. (Moorfields Eye) Hospital was held at the Langham Hotel on Thursday, February 7, 1929.

Mr. C. H. Usher, Consulting Ophthalmic Surgeon to the Royal Infirmary, Aberdeen, was in the Chair and 70 students and guests were present.

Among the guests were Sir John Rose Bradford, K.C.M.G.; Vice-Admiral Arthur Gaskell, C.B.; Air Vice-Marshal David Munro, C.B.; Professor G. Elliot-Smith and Mr. Theodore Luling.

The various toasts were given by the Chairman, Mr. J. H. Fisher and Sir John Parsons and were responded to by Sir John Rose Bradford, Mr. Theodore Luling, Marshal D. Munro and Mr. Goulden.

During the evening the Dean (Mr. Goulden) presented the following report :

The prosperity of the School continues and our admission of new students creates a record; it amounted to 134 , our previous highest number being 121 in 1925 . The number of students who attended the practice of the Hospital was 182, rather less than during 1926-1927. During the past year, October, 1927 to October, 1928,406 lectures were given by the members of the staff with the assistance of $\mathrm{Mr}$. Hume, the lecturer in anatomy, and $\mathrm{Mr}$. Brinkworth, in physics.

Among the successes gained at examinations by students last year, two received the Diploma of F.R.C.S. of Edinburgh ; at the final examination for the Diploma in Ophthalmic Medicine and Surgery of the Conjoint Board, of the 59 candidates who presented 